\title{
STUDYING THE INSULATING PROPERTIES OF OXIDE FILMS OBTAINED ON THE TI6A14V ALLOY IN TARTARIC ACID SOLUTIONS USING THE METHOD OF ELECTROCHEMICAL DECORATION BY COPPER
}

\author{
Oleksiy Pylypenko1, ${ }^{凶}$, Olga Smirnova ${ }^{2}$, Olga Skorynina-Pohrebna ${ }^{3}$, Oleksandr Khoroshev ${ }^{3}$
}

https://doi.org/10.23939/chcht15.04.526

\begin{abstract}
The investigation data of the formation peculiarities of oxide films on the Ti6A14V alloy in tartaric acid solutions have been given. It is shown that the behavior of alloy forming dependences is conditioned by the anode current density. At $j_{\mathrm{a}}<0.5 \mathrm{~A} \cdot \mathrm{dm}^{-2}$ the continuous oxide film is not formed on the alloy surface and the preset value of the final voltage on the cell is not reached. With an increase in $j_{\mathrm{a}}>0.5 \mathrm{~A} \cdot \mathrm{dm}^{-2}$, alloy forming dependences show a linear behavior that is indicative of the formation of low porous films. In these conditions, the oxide film formation rate is in direct proportion to the value of $j_{\mathrm{a}}$. The electrochemical oxidation of Ti6A14V alloy in tartaric acid solutions results in the formation of interference-colored oxide films. The oxide film ultimate thickness and color are defined by the preset voltage and are independent of the current density and electrolyte concentration. The isolating properties of obtained films were studied by the way of the cathode polarization of oxidized specimens in the sulfate copper-plating electrolyte. The research done allows us to make a conclusion that electrochemical copper deposition is a convenient tool for the detection of defective spots in oxide films. It is shown that due to the specific features of the reduction kinetics of $\mathrm{Cu}^{2+}$ ions on the oxidized titanium it is reasonable to use for the studies the initial sections of polarization dependences that correspond to $\Delta E=0.2-0.25 \mathrm{~V}$. The alloy polarization dependences allow us to establish unavailability of apparent dependences between the oxidation current density, the electrolyte concentration, the cell final voltage
\end{abstract}

\footnotetext{
${ }^{1}$ O. M.Beketov National University of Urban Economy in Kharkiv, 17, Marshal Bazhanov St., Kharkiv, 61002, Ukraine

${ }^{2}$ National Technical University "Kharkiv Polytechnic Institute",

2, Kyrpychova St., Kharkiv, 61002, Ukraine

${ }^{3}$ National University of Civil Defense of Ukraine,

94, Chernichevska St., Kharkiv, 61023, Ukraine

opilipenko1984@gmail.com

(C) Pylypenko O., Smirnova O., Skorynina-Pohrebna O.,

Khoroshev O., 2021
}

value and the polarization that occurs during the $\mathrm{Cu}^{2+}$ ion reduction. The anodic connection of copper-coated specimens conditions the reversible dissolution of a greater portion of the specks of copper deposits. It is indicative of the electron conduction of film defects. The obtained data allow us to vary the electrolysis parameters in a wide range with no significant influence of the treatment mode of Ti6A14V alloy on the quality of oxide coatings.

Keywords: anode polarization, oxide film, electrochemical deposition, polarization dependence, defect.

\section{Introduction}

Titanium and titanium alloys are used by different technologies to manufacture the items that combine a high specific strength with a low weight and chemical stability $[1,2]$. Pure titanium is a ductile and soft metal therefore titanium alloys are in high demand. Titanium alloys are widely used for the fabrication of medical implants. In this case, a mechanical strength of the material is of great importance, because the implants are exposed to variable loadings. The titanium alloy Ti6A14V (VT6) is attributed to such materials with acceptable processing properties [3]. Its drawback is that it can be subjected to the corrosion failure when placed for the operation inside the physiological body environment. The corrosion results in the surface damage of implants and the spalling of metal particles that may result in the inflammatory processes of tissues. Providing the biocompatibility of implants for the fast growth of bone tissue around the implant and eliminating clinical side effects after the osteo-integration is also of great importance. To impart the biocompatibility and increased corrosion resistance the surface of titanium materials is modified by the formation of ceramic, phosphate or oxide coatings.

The method of anode oxidation is considered to be the most promising for the formation of oxide films on 
titanium materials [4-11]. The use of electrochemical methods enables an easy control of the formation process of oxide films getting the layers of a specified thickness and different structure. It is related to the fact that the titanium surface oxidation runs easier in water solutions than its dissolution.

In acid electrolytes, steady-state titanium potentials are located in the domain of positive values and it is indicative of that the titanium surface is strongly oxidized even without anode polarization. In neutral, weak-acid and alkaline environments the films of mixed oxides $\mathrm{Ti}_{2} \mathrm{O}_{3}-\mathrm{TiO}_{2}$ with the dominance of the oxides of an ultimate degree of oxidation $\mathrm{Ti}_{5} \mathrm{O}_{9}$ and $\mathrm{Ti}_{6} \mathrm{O}_{11}$ are formed on the titanium surface at self-passivation potentials or anode polarization. At the potentials higher than the oxygen release potential the composition and structure of passive films are changed due to the transition of the oxides of a variable composition into the higher titanium oxide.

The anodic oxidation of titanium materials in severe conditions (the air oxidation at high temperatures or oxidation in oxidizing media at their boiling temperatures and/or the anode oxidation at high potentials) results in the formation of $\mathrm{TiO}_{2}$ films with the anatase structure containing a small amount of rutile admixture.

The oxide film structure formed during the electrochemical titanium oxidation depends on the composition of the used electrolyte. The anodizing in the electrolytes that interact weakly with oxide film results in the formation of thin passive layers that are tinted at the interface due to the light interference [7, 8]. The addition of activating ions to the electrolyte composition results in the formation of porous oxide films with the wide range of the densities of the pores arrangement and their diameters [12-15]. Such films can be used as a matrix for its subsequent filling to form composite coatings [16, 17].

The dense films consisting of $\mathrm{TiO}_{2}$ have the mixed ion-electron conductivity. At shallow film thickness the electron conductivity provides the progress of electrochemical processes at the oxide-electrolyte boundary. The barrier layer with a high specific electric resistance is formed due to a low value of electron conductivity with a further increase in the film thickness and it abruptly limits the anode current density at a given potential value [8]. Particularly this property of dense oxide films provides a high corrosion resistance for titanium materials in oxidizing media.

From the standpoint of the electrochemical activity of titanium implants, the properties of oxide films are of interest for the prediction of their corrosion resistance in the physiological body environment. It is known that in addition to the composition, the protective properties of oxide films are also defined by their porosity and thickness. A thickness of the film obtained using the electrochemical method is defined by the potential value; the porosity is defined by the type of electrolyte, the electrolysis mode and the alloy composition. In the case of oxide films applied onto titanium materials, the main corroding factor is the defects that disturb the oxide film continuity. The corrosion of titanium materials with the ideal oxide coating should be a minimum due to a high ohmic resistance of $\mathrm{TiO}_{2}$.

Many scientific papers are devoted to the studies of the protective properties of films deposited onto titanium. For example, the protective properties of oxide films applied onto titanium oxidized in $\mathrm{H}_{2} \mathrm{SO}_{4}$ were studied in the scientific paper [18]. It is shown that the oxide films obtained in the potentiostatic mode provide an increased corrosion resistance for the pure titanium of a TA2 grade. An increase in the oxidation voltage improves the corrosion resistance of oxide. The electrochemical behavior of medical alloys Ti-6Al-4V, Ti-6Al-7Nb and Ti-13Nb-13Zr was studied in the scientific paper [19] to evaluate their corrosion resistance in the physiologic solution. Polarization measurements showed that the studied materials are characterized by a low corrosion current densities that are indicative of the passive state of studied alloys. The influence of the treatment mode of materials on the corrosion properties of films was not studied. The scientific paper [20] studies the influence of oxide films on the corrosion behavior of Ti-3Mo alloy. It is shown that the anodizing results in the formation of semiconducting films that are characterized by the electrochemical stability in the internal environment. The data were obtained for the specimens oxidized in phosphate acid solutions. The electrochemical behavior of Ti-6Al-4V alloy in the physiological solution was studied in the scientific paper [21]. The purpose of this research was to estimate the corrosion resistance of alloy. Low corrosion current values were obtained for the Ti-6Al-4V alloy in comparison to those of magnesium alloy AZ91D that is indicative of the typical passive behavior of titanium. The scientific paper [22] delves into the corrosion behavior of Ti-15Mo alloy in chloride solutions with different concentrations of Fions that was studied using the methods of potentiodynamic curves, impedance and chronoamperometry. The research data show a strong dependence of the corrosion resistance of alloy on the concentration of $\mathrm{F}^{-}$ions in the electrolyte. The corrosion of medical titanium alloy Ti-24Nb-4Zr- $8 \mathrm{Sn}$ in the $0.9 \%$ $\mathrm{NaCl}$ solution was studied in [23]. The electrochemical corrosion behavior was studied using the method of potentiodynamic polarization curves and the MottSchottky method. It is shown that the protective film structure depends on the alloy treatment mode. An effect of the alloy oxidation mode was not studied. The anode oxide films that were obtained on pure titanium in $1 \mathrm{M}$ 
sulfuric and phosphate acids were studied in [24]. It is shown that an increase in the forming voltage conditions results in an increase in the corrosion resistance of oxide films. The films obtained in the phosphate acid are more resistant in comparison to those obtained in sulfuric acid due to lower electrolyte corrosivity. The scientific paper [25] is devoted to the studies of the corrosion resistance of titanium and nitinol anodized in the acetic acid and Ti$6 \mathrm{Al}-7 \mathrm{Nb}$ anodized in the physiological solution. It was established that the formation of $\mathrm{TiO}_{2}$ on the surface of specimens resulted in a significant increase in the polarization resistance and a decrease in the corrosion current density. The corrosion behavior of $\mathrm{Ni}-\mathrm{Ti}$ and $\mathrm{Ti}-$ $\mathrm{Nb}-\mathrm{Sn}$ alloys in chloride solutions was studied in [26] using the methods of potentiometry and electrochemical impedance. Corrosion potential values are indicative of the fact that $\mathrm{Ni}-\mathrm{Ti}$ and $\mathrm{Ti}-\mathrm{Nb}-\mathrm{Sn}$ alloys are exposed to the spontaneous passivity due to the spontaneously formed oxide film. The electrochemical impedance of all the specimens has a high value and it is increased at the exposure to the action of chloride solutions that is indicative of improved corrosion resistance of oxide film. The influence of bromide ions on the passive state indices of anodized titanium was considered in the scientific paper [27]. It was shown that availability of bromine ions conditions the origination of point breakdowns of oxide films and it can be used for the formation of films with the ordered structure. Corrosion properties of titanium with the mixed boron and metal coating were studied using the spectra of electrochemical impedance [28]. The anode polarization that lasted for about 240 hours resulted in higher capacitance and reaction resistance values for the specimens made of titanium materials with the mixed coating. The scientific paper [29] studies the influence of a long-term anodizing on the properties of oxide formed on the Ti-6Al-2Zr-1Mo-1V alloy. It is established that the oxide layer formation passes through the stages of formation of compact inner layer and porous outer layer. The passive properties of films were not studied. The paper [30] studies the influence of the layer thickness on the corrosion resistance of Ti6Al4V alloy. The behavior of the specimens exposed to the polarization and corrosion potentials have been studied. It is established that the anodizing of Ti6Al4V alloy results in the improvement of its corrosion characteristics, however, an increase in the forming voltage degrades the corrosion properties of films. The porous oxide films that were obtained using the method of electrochemical anodizing in the fluoride electrolyte were studied in [31]. It is established that the corrosion and the disposition to the pitting are decreased in the case of alloy anodizing. According to the research described in [30], the anodizing in the alkaline bath was used for the formation of interference-colored films on pure titanium. The obtained data show that compact and uniform films consisted of $\mathrm{TiO}_{2}$ and $\mathrm{Ti}_{2} \mathrm{O}_{3}$ and had a good adhesion and high corrosion resistance.

Thus, the review of the research done allows us to draw a conclusion on the insufficient amount of data relating to the influence of electrolysis mode on the insulating properties of oxide films obtained using the method of electrochemical oxidation in the solutions of carbonic acids. The research done in this field will be a precondition for the development of the controlled method of the formation of films with preset properties.

The purpose of this research was to study the influence of the electrolysis mode on the insulating properties of oxide films obtained on the Ti6Al4V alloy in tartaric acid solutions.

\section{Experimental}

The oxidation was performed in a galvanostatic mode presetting the cell voltage in the range of $10-100 \mathrm{~V}$ using the power supply source of a B5-50 type. The voltage was measured by Keithley-2000 multimeter. The alloy plates of $70 \times 20 \times 5 \mathrm{~mm}$ were used as the specimens. The specimens were grinded using the emery paper and degreased in the $\mathrm{Na}_{2} \mathrm{CO}_{3}$ suspension with the subsequent etching in the $\mathrm{HNO}_{3}$ and $\mathrm{HF}$ mixture (3:1). The specimens were rinsed with water between the operations. The cup of $250 \mathrm{ml}$ made of chemically resistant glass was used as a cell. The electrolyte temperature was equal to $293 \mathrm{~K}$. To prevent the heating of electrolyte by the current the cup was placed into the crystallizer with the volume of 51 filled with water. The lead was used as an additional electrode. The electrolysis time was defined by the preset voltage $U$. A signal to the process termination was the actuation of the relay switching the power supply source from the direct current mode to the d.c. voltage mode.

The film thickness was calculated using Faraday's law. Coulometric data obtained from the results of galvanostatic electrolysis were used for the calculation.

Electrochemical decoration was performed by the way of the cathode polarization of oxidized specimens in the sulfate electrolyte of the following composition: $\mathrm{CuSO}_{4} \cdot 5 \mathrm{H}_{2} \mathrm{O} \quad 100 \mathrm{~g} \cdot 1^{-3}, \mathrm{H}_{2} \mathrm{SO}_{4} \quad 50 \mathrm{~g} \cdot 1^{-3}$. Cathode polarization dependences were obtained in the potentiodynamic mode $v_{\mathrm{s}}=10 \mathrm{mV} \cdot \mathrm{s}^{-1}$ using the potentiostat PI-50-1. The electrode potential sweep was performed in the range of $E_{\mathrm{st}}$ to $E_{\mathrm{j}}=(-0.4)-(-0.8) \mathrm{V}$. From the standpoint of research, the sections of dependences corresponding to the electrode polarization of 0.2 to $0.25 \mathrm{~V}$ were of interest. The reference electrode was the chloride-silver electrode EVL-1M1. The potentials on the curves are given in the scale of this electrode.

To do the research the reagents of analytical grade were used. 


\section{Results and Discussion}

\subsection{Studying the Formation of $\mathrm{TiO}_{2}$ in Tartaric Acid Solutions at the Anode Polarization}

Carbon acid-based electrolytes are used for the formation of interference-colored oxide films [32]. In the case of formation of low-porous oxides in $\mathrm{C}_{4} \mathrm{H}_{6} \mathrm{O}_{6}$ solutions that have a weak etching effect with regard to $\mathrm{TiO}_{2}$ we expect a linear increase in the cell voltage in the galvanostatic oxidation mode. This assumption is confirmed by experimental data. Ti6Al4V alloy forming dependences (Fig. 1) show that the anode current density $j_{\mathrm{a}}$ has a decisive influence on the oxidation procedure. At $j_{\mathrm{a}}=0.2-0.5 \mathrm{~A} \cdot \mathrm{dm}^{-2}$ the dependences have a nonlinear character and these are not often reproduced (Fig. 1, lines 1 and 2). At $j_{\mathrm{a}}=0.2 \mathrm{~A} \cdot \mathrm{dm}^{-2}$ the preset value of $U$ is not achieved and it can be explained as follows: the electrochemical metal oxidation contributes to an increase in the film thickness and in the cell $U$ value due to a high ohmic resistance of $\mathrm{TiO}_{2} \quad\left(\rho=10^{13} \mathrm{Ohm} \cdot \mathrm{m}\right)$. Simultaneously, $\mathrm{TiO}_{2}$ interacts chemically with electrolyte components and this interaction results in a decreased film thickness and resistance, accordingly. The horizontal plato in the dependence 1 (Fig. 1, line 1) is indicative of the stationary process at which the $\mathrm{TiO}_{2}$ formation rate is equal to that of its chemical dissolution. At $j_{\mathrm{a}}=0.5 \mathrm{~A} \cdot \mathrm{dm}^{-2}$ (Fig. 1, line 2), we observe the origination of plato after which a gradual increase in the voltage is observed with the final yield of the preset $U$ value. An increase in $j_{\mathrm{a}}$ values exceeding $1 \mathrm{~A} \cdot \mathrm{dm}^{-2}$ conditions the linear character of the dependences 3 and 4 (Fig. 1, lines 3 and 4) with the natural increase in the $U$ value with an increase in the alloy oxidation rate. A linear shape of the dependences 3 and 4 in is indicative of the fact that the oxidation results in the formation of films with a minimum porosity that should have good protective properties.

The color of obtained films is conditioned by the light interference at the "film-air" boundary and it is defined by the oxide thickness (Table 1).

The time $\tau$ required for the attainment of the ultimate film thickness during the oxidation in the galvanostatic mode depends only on the final $U$ (Fig. 2). The reason for this effect is that the oxidation is possible on condition of availability of a specific potential gradient in the film. The film thickness ceases to increase at reaching the potential gradient that cannot provide the passage of ions through oxide. Therefore, it is evident that in the galvanostatic mode an increase in the preset forming $U$ will contribute to the formation of a thicker film due to an increase in the amount of current flowing through the cell.

The film growth is possible on condition of availability of a specified value of the voltage drop through-the-thickness of oxide that provides the motion of ions in the $\mathrm{TiO}_{2}$ lattice. A decrease in the gradient in the conditions of preset $U$ results in the termination of oxide growth. At $j_{\mathrm{a}}=$ const an increase in $U$ will result in an increase of the maximum thickness of oxide or the electrolysis time proportional to it [33]. The effect is independent of other process parameters and it is confirmed by the experimental data.

\subsection{Studying the Insulating Properties of Oxide Films by the Method of Electrochemical Decoration by Copper}

The insulating properties of oxide films were studied using the method of decoration, the essence of which consists in that the oxidized specimens are exposed to the cathode polarization in the electrolyte and the reduction of its ions enables the formation of metal deposits in the film defects [34].

Table 1

The color of obtained films is conditioned by the light interference at the "film-air" boundary and it is defined by the oxide thickness

\begin{tabular}{|c|c|c|}
\hline$U, \mathrm{~V}$ & Film color & Film thickness, $\mu \mathrm{m}$ \\
\hline 10 & brown & 0.037 \\
\hline 20 & dark blue & 0.064 \\
\hline 30 & blue & 0.101 \\
\hline 40 & light green & 0.119 \\
\hline 50 & yellow & 0.147 \\
\hline 60 & golden & 0.193 \\
\hline 70 & crimson & 0.220 \\
\hline 80 & dark turquoise & 0.229 \\
\hline 90 & light turquoise & 0.273 \\
\hline 100 & green & 0.275 \\
\hline
\end{tabular}




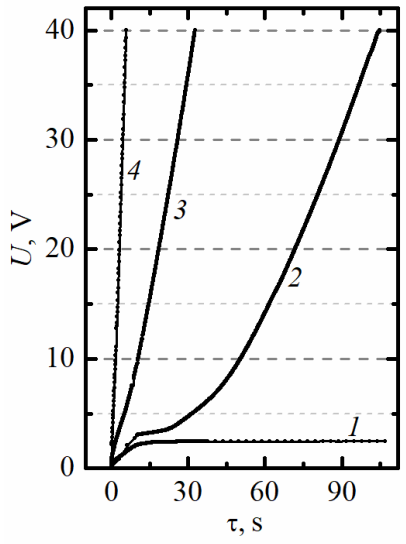

Fig. 1. The Ti6Al4V alloy forming dependences obtained in the tartaric acid solutions at $j_{\mathrm{a}}$, $\mathrm{A} \cdot \mathrm{dm}^{-2}: 0.2$ (1), $0.5(2), 1.0$ (3) and 5.0 (4). $c_{\mathrm{A}}=50 \mathrm{~g} \cdot \cdot^{-3}$; the final value of $U=40 \mathrm{~V}$

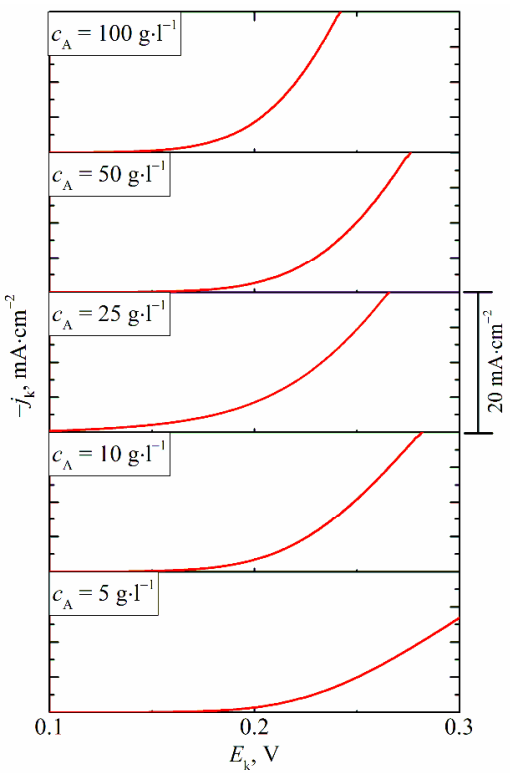

Fig. 3. Cathode polarization dependences obtained for the oxidized Ti6A14V alloy in the sulfate electrolyte.

Dependencies obtained for the specimens oxidized at $j_{\mathrm{a}}=2$ A $\cdot \mathrm{dm}^{-2}$ reaching the final value of $U=40 \mathrm{~V}$

The typical dependences that allow for the rough estimation of film defectiveness are the polarization curves of electrochemical processes that proceed on oxidized alloy specimens.

Polarization dependences obtained for oxidized alloy specimens in the sulfate electrolyte are given in Figs. $3-5$. The biasing of potential of all tested specimens from $E_{\mathrm{st}}$ to the domain of negative values results in an increased current density that corresponds to the reduction process of copper ions on the defective spots of oxide film. A change in the concentration of tartaric acid (Fig. 3) and the

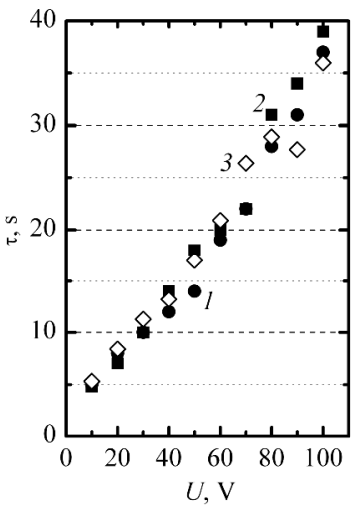

b)

a)

Fig. 2. The dependences of $\tau-f(U)$ obtained in the galvanostatic mode during he Ti6Al4V alloy oxidation in tartaric acid: a) the dependences of $\tau-f(U)$ obtained at $c_{\mathrm{A}}, \mathrm{g} \cdot \mathrm{l}^{-3}: 100(1), 50(2), 25$ (3), 10 (4) and 5 (5);

b) the dependences of $\tau-f(U)$ obtained at $j_{\mathrm{a}}, \mathrm{A} \cdot \mathrm{dm}^{-2}: 5(1), 2$ (2) and 1 (3)

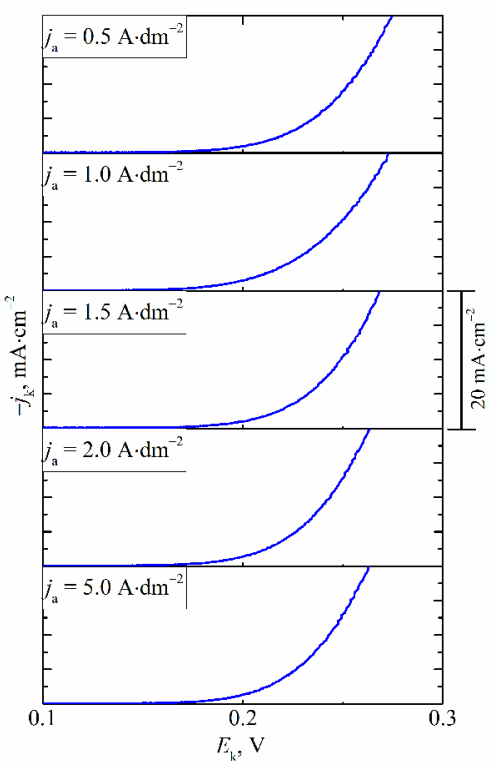

Fig. 4. Cathode polarization dependences obtained for the oxidized Ti6A14V alloy in the sulfate electrolyte.

Dependences obtained for the specimens oxidized at $c_{\mathrm{A}}=50 \mathrm{~g} \cdot \mathrm{dm}^{-3}$ reaching the final value of $U=40 \mathrm{~V}$

oxidation current density (Fig. 4) has actually no effect on oxide film insulating properties. A slight difference in the current density for the specimens oxidized in the conditions of varied $c_{\mathrm{A}}$ and $j_{\mathrm{a}}$ values proves that. The same situation is observed in the case of the decoration of specimens oxidized at a changed final voltage value in the cell (Fig. 5).

An ideal defect-free oxide film consisting of $\mathrm{TiO}_{2}$ should possess wonderful insulating properties due to a very high ohmic resistance of titanium dioxide conditioned by a high value of specific resistance $\left(10^{13} \mathrm{Ohm} \cdot \mathrm{m}\right)$. In 
reality, the oxide film resistance is much lower, because it contains electrolyte components and has the defects caused by foreign inclusions and mechanical stresses that occur during the electrochemical formation of oxide film and result in the origination of cracks in the oxide film $[35,36]$. The polarization measurement data show that the insulating properties of obtained oxide films are approximately the same in all the cases. A value of the electrode polarization at the cathode reduction of copper ions is indicative of that. The electrode polarization values of $\Delta E\left(\right.$ at $\left.j_{\mathrm{k}}=5 \mathrm{~mA} \cdot \mathrm{cm}^{-2}\right)$ that are given in Table 2 show that the dependence between the alloy oxidation mode parameters and the copper reduction process polarization values is not observed.

The basic conclusion that can be made based on polarization dependences consists in that a change in the oxidation mode has actually no effect on the insulating properties of oxide films obtained in tartaric acid solutions. Though, at first sight the polarization dependences obtained in changed oxidation conditions have essential differences from the standpoint of curve shapes and the value of electrode polarization, however their comparison is erroneous on the whole. It will be more appropriate to give consideration to the initial sections of dependences that correspond to $\Delta E$ of 0.2 to $0.25 \mathrm{~V}$. The reason for this is a rapid increase in the area of copper deposition on the specimen surface that conditions an extremely fast increase in the current and distorts the data that allow us to judge about availability of oxide defects. Magnified sections of the curves shown in the insets in Figs. 3 and 4 prove that the behavior of dependences for all the specimens is approximately the same, in other words approximately the same polarization values correspond to actually the same current density. Certain differences that can be seen are conditioned by a difference in the area of working electrodes and also by an insufficient number of experimental data. The processing of large data arrays would enable the generation of more averaged results. The dependences in Fig. 4 also allow us to draw the same conclusion. An increase in the value of final voltage in the cell that can be achieved due to the growth of oxide in the galvanostatic mode would result in the proportional increase in the film thickness. In the case of the defect-free film it would condition an increase in the electric resistance of the film of a barrier type and an increased polarization of the process of copper release on the specimens. In reality, it fails to happen and the behavior of the initial sections of polarization dependences obtained in the conditions of an increase in the preset final $U$ (Fig. 5) is actually the same. A possible explanation of this effect will be given in the next section.

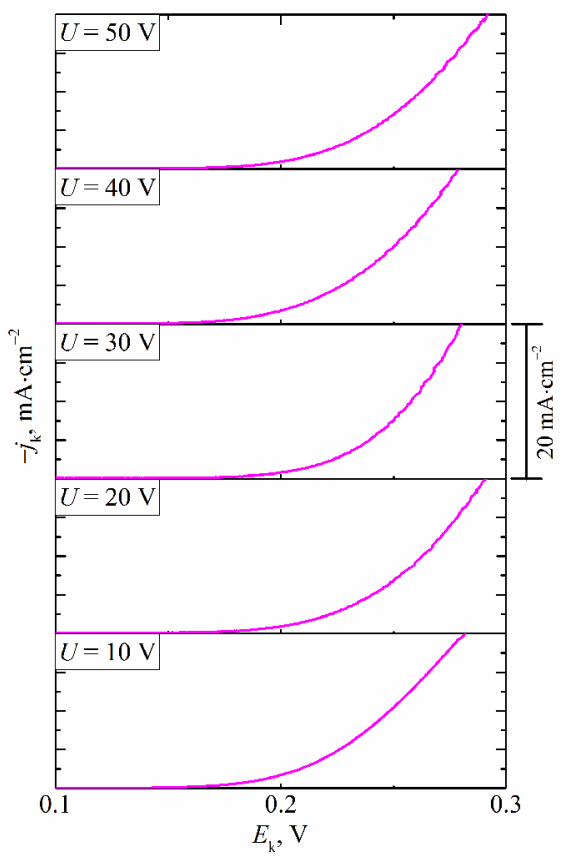

a)

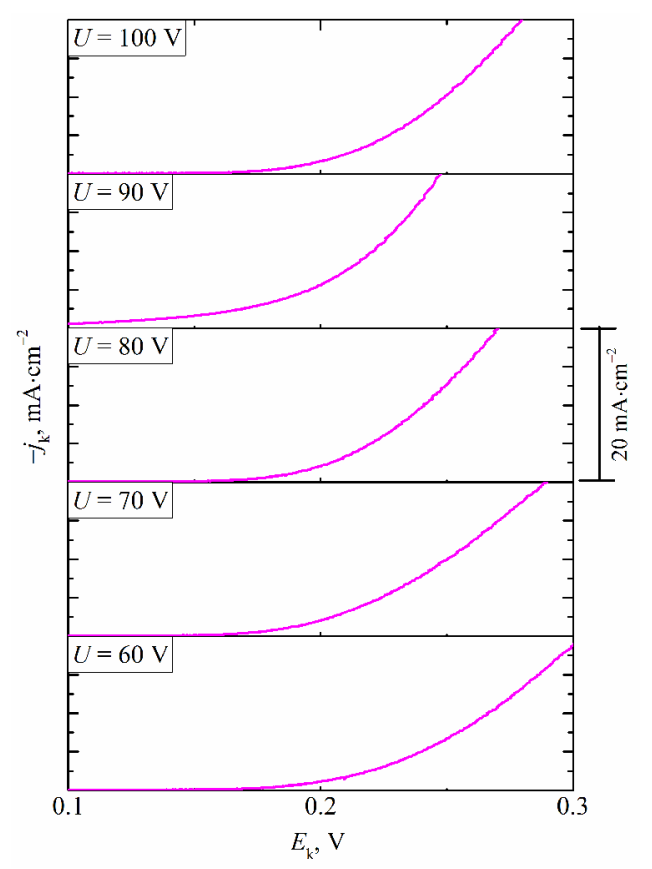

b)

Fig. 5. Cathode polarization dependences obtained for the oxidized Ti6A14V alloy in the sulfate electrolyte. Dependences obtained for the specimens oxidized at $j_{\mathrm{a}}=2 \mathrm{~A} \cdot \mathrm{dm}^{-2}, c_{\mathrm{A}}=50 \mathrm{~g} \cdot 1^{-3}$, reaching the final value of $U=10-100 \mathrm{~V}$ 
The correspondence between the electrolysis mode and the polarization value of $\Delta E$ of the reduction of copper ions

\begin{tabular}{|c|c|c|c|c|c|}
\hline \multicolumn{6}{|c|}{ Oxidation mode } \\
\hline \multicolumn{2}{|c|}{$j_{\mathrm{a}}=2 \mathrm{~A} \cdot \mathrm{dm}^{-2}, U=40 \mathrm{~V}$} & \multicolumn{2}{|c|}{$c_{\mathrm{A}}=50 \mathrm{~g} \cdot 1^{-3}, U=40 \mathrm{~V}$} & \multicolumn{2}{|c|}{$j_{\mathrm{a}}=2 \mathrm{~A} \cdot \mathrm{dm}^{-2}, c_{\mathrm{A}}=50 \mathrm{~g} \cdot \mathrm{l}^{-3}$} \\
\hline$c_{\mathrm{A}}, \mathrm{g} \cdot \mathrm{dm}^{-3}$ & $\Delta E, \mathrm{~V}$ & $j_{\mathrm{a}}, \mathrm{A} \cdot \mathrm{dm}^{-2}$ & $\Delta E, \mathrm{~V}$ & $U, \mathrm{~V}$ & $\Delta E, \mathrm{~V}$ \\
\hline 5 & 0.250 & 0.1 & 0.230 & 10 & 0.205 \\
\hline 10 & 0.225 & 1.0 & 0.220 & 20 & 0.240 \\
\hline 25 & 0.210 & 1.5 & 0.220 & 30 & 0.240 \\
\hline 50 & 0.230 & 2.0 & 0.225 & 40 & 0.225 \\
\hline \multirow[t]{6}{*}{100} & 0.205 & 5.0 & 0.235 & 50 & 0.240 \\
\hline & & & & 60 & 0.210 \\
\hline & & & & 70 & 0.220 \\
\hline & & & & 80 & 0.220 \\
\hline & & & & 90 & 0.218 \\
\hline & & & & 100 & 0.220 \\
\hline
\end{tabular}

\subsection{Results Discussion}

The electrochemical oxidation of Ti6A14V alloy in tartaric acid solutions results in the formation of oxide interference-colored films on the metal surface. The current density and the cell final voltage value are the main electrolysis parameters that define the growth dynamics and the limiting electrolysis time that corresponds to a maximum film thickness achieved under the given conditions [37]. Alloy forming dependences (Fig. 1) are indicative of the fact that an increase in $j_{\mathrm{a}}$ contributes to an increase in the oxide film growth rate. This observation is in full compliance with fundamental electrolysis laws according to which the current density conditions the electrochemical metal oxidation rate. A linear character of the dependences $U-f(\tau)$ at $j_{\mathrm{a}}>0.5 \mathrm{~A} \cdot \mathrm{dm}^{-2}$ is indicative of the formation of low-porous oxide films whose electrical resistance is in proportion to their thickness. Such conclusion can also be drawn based on the data given in Fig. 2. The thickness of oxide film formed at $j_{\mathrm{a}}=$ const depends only on the value of preset final $U$. At $j_{\mathrm{a}}=$ const, an increase in $U$ will result in an increase in a maximum oxide thickness or the electrolysis time proportional to it. The effect must not depend on other process parameters and it is confirmed by experimental data (Fig. 2). On the whole, the research data of the oxidation process of Ti6A14V alloy keep perfectly well with the framework of the theory of the electrochemical growth of the oxide layers of a barrier type according to which the film growth is possible at the availability of the specific value of potential gradient (voltage drop) in the oxide that provides the motion of ions in the $\mathrm{TiO}_{2}$ lattice. An increase in the film thickness at the galvanostatic oxidation results in a decrease of the potential gradient and it results in the regular oxide growth cessation in the conditions of preset $U$.
The research data obtained for the processes that proceed at the cathode polarization of oxidized specimens in the sulfate electrolyte should be also discussed. The method of electrochemical decoration is a convenient tool that allows for an easy and accurate visualization of available defects in the oxide film. The copper decoration allows for the detection of defects that can be counted using the metallographic microscope of a low magnification. The obtained data are considered to be a valuable material that allows us to define the influence of the formation conditions of oxide layer on its quality, and using the data of other investigations we can define oxidation modes for the formation of films with optimal protective properties. In addition, the decoration allows us not only to detect available defects in the oxide film but also to study their nature. The cathode connection of specimens conditions the deposition of metals in the places of disturbed oxide layer. The selection of copper for the decoration is conditioned by the convenience because the copper deposition results in the formation of colored rosy deposit that can easily be seen on the specimen surface.

To detect an effect of the oxidation mode on film insulating properties it is reasonable to consider only the initial sections of polarization dependences confining to the polarization value varied in the range of $0.2-0.25 \mathrm{~V}$. Even at such polarization the deposition of copper occurs in the conditions of diffusion kinetics. In these conditions, the process rate is defined by the retarded stage of the delivery of copper ions to defective film spots. The fact that at the potential sweep of oxidized specimen to the cathode region, copper ions are reduced in the mode of concentration polarization which is confirmed by the polarization dependence obtained for the smooth copper electrode in the same electrolyte (Fig. 6). A value of the cathode current density on the site in Fig. 6 is equal to 
$7.5 \mathrm{~mA} \cdot \mathrm{cm}^{-2}$ and this current density corresponds to a maximum admissible current density of the reduction of $\mathrm{Cu}^{2+}$ ions. It will be natural to assume that the limiting current density in the case of oxidized electrode will be much lower due to the fact that such system can be considered as the electrode-coated with the insulating film in which defective spots will be considered as possible zones for the copper deposit appearance and growth. The total area of such sites will be much smaller than that of the smooth copper electrode, therefore it is reasonable to assume that the limiting current density on the oxidized surface will onset at lower $\Delta E$ values in comparison to that on the smooth surface. In reality, the polarization dependences in Figs. 3 and 4 show no limiting current site at the values of $\Delta E=0.1-0.3 \mathrm{~V}$. It is governed by the fact that the cathode polarization on defect sites conditions the high values of current densities that in their turn result in a rapid development of the deposit and a decrease in the cathode polarization value.

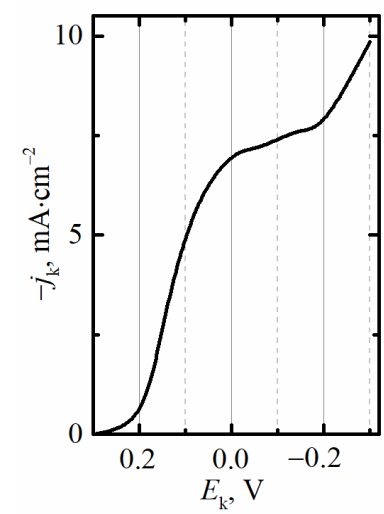

Fig. 6. Cathode polarization dependence obtained for the smooth copper electrode in the sulfate electrolyte

After the potential of $\approx(-0.2 \mathrm{~V})$ is reached a rapid increase in the current density is observed sometimes with the subsequent manifestation of the bending that corresponds to the limiting current density. The analysis of dependences in this domain is of no use from the scientific standpoint because an increase in the current is a consequence of the rapid enlargement of the deposit area of copper that was reduced on the initial defect spots of the film. As a result the copper deposition changes to the diffusion mode and the formation of the porous deposit of a brick red color proves that. This deposit can easily be removed from the specimen surface by a finger or the filter paper. An enlargement of the deposit area also creates insurmountable difficulties relating to a further computation of growth points on the specimen surface.

It should be noted that the decoration allows us to establish the two types of defects on the surface of oxidized specimens. The defects of the first type are characterized by a change in the electrode polarity after the formation of deposit that results in a complete dissolution of released copper. It is evident that the copper dissolution-deposition process reversibility is indicative of that the defects of the first type provide a free passage of the electrons from the substrate metal through the film to the electrolyte. Such defects can be represented by foreign inclusions with the electron conduction, through pores or the cracks that appear during the oxidation [38-40]. The dissolution of copper is not observed on the defects of the second type in the case of the anode connection of specimens.

In addition to the copper reduction, the reduction of oxide films on the alloy is possible at the cathode connection of specimens. The cathode polarization of oxidized specimens in tartaric acid solutions results in a change of color of the oxide film that is indicative of film restructuring processes. However, there is no reset to the initial gray-steel surface and the specimens remain uncolored. One more argument in favor of this assertion is the behavior of such cathode-polarized specimens in the etching solution. During the treatment, we observe a gradual change in the film color and only after the disappearance of it the metal is exposed to the etching with the release of gas bubbles. The cathode polarization of oxidized specimens in the sulfate electrolyte also results in no noticeable change in the film color. Therefore, it is evident that the oxide layer is not reduced completely. Otherwise, this process would result in the deposition of copper in the form of solid deposit. However, it was not observed during the experiment.

A similarity of the initial sections of polarization dependences given in Figs. 3 and 4 can be also explained. The dependences were obtained for the specimens that were oxidized in the galvanostatic mode with the final voltage value equal to $40 \mathrm{~V}$. It is evident that in this case the insulating properties of films are defined by their thickness $\delta$ (final $U$ ) that is approximately the same for all the cases and a change in the acid concentration or the current density is of secondary importance. It is more difficult to explain the similarity of the curves given in Fig. 5. An increase in the value of final $U$ that is reached during the electrolysis in the galvanostatic mode would result in the formation of thicker films. The computation based on the Faraday law in assumption that the oxide film consists of $\mathrm{TiO}_{2}$ shows that at $U=10 \mathrm{~V}$ the film thickness is equal to approximately $0.04-0.05 \mu \mathrm{m}$ and as the $U$ value is increased reaching $100 \mathrm{~V}$ the film thickness is varied in the range of $0.037-0.275 \mu \mathrm{m}$. It is quite possible that the decisive factor in this case is not the film thickness, but the peculiarities of its structure [41] and it requires an additional research in this field. 


\section{Conclusions}

The formation process of oxide films on the Ti6A14V alloy in tartaric acid solutions has been studied. Analysis of alloy-forming dependences showed that the oxidation dynamics is defined by the used current density. At $j_{\mathrm{a}}<0.5 \mathrm{~A} \cdot \mathrm{dm}^{-2}$, solid oxide films are not formed on the alloy and the preset final voltage is not reached. At $j_{\mathrm{a}}>0.5 \mathrm{~A} \cdot \mathrm{dm}^{-2}$, we observe the linear character of forming dependences. The electrochemical alloy oxidation in these conditions results in the formation of interference-colored oxide films. The limiting electrolysis time that corresponds to a maximum film thickness that can be achieved for the given conditions is defined by the preset $U$ value and it is independent of the electrolyte concentration and the used current density.

The method of electrochemical decoration was used for the investigation of the insulating properties of the films obtained on the Ti6A14V alloy. The cathode polarization of oxidized alloy specimens in the sulfate electrolyte results in the reduction of $\mathrm{Cu}^{2+}$ ions with the formation of the deposit on the oxide film surface in the form of individual spots. It is shown that a change in the oxidation mode, tartaric acid concentration, oxidation current density, final cell voltage has an insignificant influence on the polarization of the reduction process of copper ions in the range of $\Delta E=0.2-0.25 \mathrm{~V}$. An obvious dependence between the oxide film formation mode and the process polarization value was not established. The biasing of potential to the domain of $\Delta E$ values that are more negative than $\Delta E=0.2-0.25 \mathrm{~V}$ conditions a rapid enlargement of the site of copper deposition and distorts the measurement data. It was established that the surface of oxidized specimens has the defects of two types. A change in the electrode polarity conditions a complete dissolution of the copper deposit on the defects of the first type; the dissolution of copper is not observed on the defects of the second type during the anode polarization. A complete reduction of the oxide film on titanium at the cathode connection is not observed.

\section{References}

[1] Chouirfa H., Bouloussa H., Migonney V. et al.: Acta Biomat., 2018, 83, 37. https://doi.org/10.1016/j.actbio.2018.10.036 [2] Jorge J., Barão V., Delben J. et al.: J. Indian Prosthodont. Soc., 2013, 13, 71. https://doi.org/10.1007/s13191-012-0190-1

[3] Adya N., Alam M., Ravindranath T. et al.: J. Indian Prosthodont. Soc., 2005, 5, 126. https://doi.org/10.4103/0972-4052.17104

[4] Gugelmina S., Santosa L., Ponteb H. et al.: Mater. Res., 2015, 18,3 .

[5] Liu Z., Zhong X., Walton J. et al.: J. Electrochem. Soc., 2016, 163, E75. https://doi.org/10.1149/2.0181603jes
[6] Langklotz U., Noeske M., Schneider M.: Mater. Corros., 2018, 69 , 1810160. https://doi.org/10.1002/maco.201810160

[7] Diamanti M., Ormellese M., Pedeferri M.: J. Exp. Nanosci., 2015, 10, 1285. https://doi.org/10.1080/17458080.2014.999261

[8] Arsov L., Mickova I.: J. Electrochem. Sci. Eng., 2015, 5, 221. https://doi.org/10.5599/jese.245

[9] Lamberti A.: Nanomaterials, 2018, 8, 325.

https://doi.org/10.3390/nano8050325

[10] Pilipenko A., Pancheva H., Deineka V. et al.: EEJET, 2018, 3, 33. https://doi.org/10.15587/1729-4061.2018.132521

[11] Ivashchenko M., Smirnova O., Kyselova S. et al.: EEJET, 2018, 5, 21. https://doi.org/10.15587/1729-4061.2018.143793

[12] Concha O., Castañeda I., Guardian R. et al.: Int. J. Electrochem. Sci., 2015, 10, 6175.

[13] Benea L., Răvoiu A., Celis J.-P.: Biomater. Sci. Eng., 2019, 5, 5925. https://doi.org/10.1021/acsbiomaterials.9b00626

[14] Liu C.-F., Lee T.-H., Liu J.-F. et al.: Sci. Rep., 2018, 8, 6623. https://doi.org/10.1038/s41598-018-24590-x

[15] Rodrigues A., Oliveira N., Santos M.: J. Mater. Sci.-Mater. M., 2015, 26, 1. https://doi.org/10.1007/s10856-014-5323-0

[16] Jimenez Cadena G., Eyraud M., Chassigneux C. et al.: Int. J. Nanotechnol, 2012, 9, 3. https://hal-amu.archives-ouvertes.fr/hal02656763/document

[17] Su Z., Zhang L., Jiang F. et al.: Prog. Nat. Sci.-Mater. Int., 2013, 23, 294. https://doi.org/10.1016/j.pnsc.2013.04.004

[18] Yang G., Ma D., Liu L. et al.: Chem. Eng. Trans., 2017, 59, 157. https://doi.org/10.3303/CET1759027

[19] Assisa S., Wolynec S., Costa I.: Electrochimica Acta, 2006, 51, 1815. https://doi.org/10.1016/j.electacta.2005.02.121

[20] Bouchemel H., Benchettara A.: Arab. J. Sci. Eng., 2014, 39, 139. https://doi.org/10.1007/s13369-013-0873-x

[21] Fekry A., El-Sherif R.: Electrochimica Acta, 2009, 54, 7280. https://doi.org/10.1016/j.electacta.2009.07.047

[22] Kumar S., Narayanan T.: J. Dentistry, 2008, 36, 500.

https://doi.org/10.1016/j.jdent.2008.03.007

[23] Li J., Li S. J., Hao Y. L. et al.: Acta Biomater., 2014, 10, 2866. https://doi.org/10.1016/j.actbio.2014.02.032

[24] Liu Z., Liu X., Donatus U., Thompson G.E. et al.: Int. J. Electrochem. Sci., 2014, 9, 3558.

[25] Milošev I., Blejan D., Varvara S. et al.: J. Appl. Electrochem., 2013, 43, 645. https://doi.org/10.1007/s10800-013-0552-3

[26] Rosalbino F., Macciò D., Scavino G. et al.: J. Mat. Sci.-Mater. M., 2012, 23, 865. https://doi.org/10.1007/s10856-012-4560-3

[27] Sazou D., Saltidou K., Pagitsas M.: Electrochimica Acta, 2012, 76, 48. https://doi.org/10.1016/j.electacta.2012.04.158

[28] Wang J., Wang W., Wang C. et al.: Int. J. Hydr. Energy, 2012, 37, 12069. https://doi.org/10.1016/j.ijhydene.2012.04.146

[29] Wu L., Liu J., Yu M. et al.: Int. J. Electrochem. Sci., 2014, 9, 5012.

[30] Łępicka M., Grądzka-Dahlke M., Sobolewski A.: Materialprufung, 2015, 57, 393. https://doi.org/10.3139/120.110725 [31] Singh A., Singh B., Wani M. et al.: Bull. Mat. Sci., 2013, 36, 931. https://doi.org/10.1007/s12034-013-0536-2

[32] Shevchenko G., Pilipenko A., Shkolnikova T. et al.: Proceed. 2020 IEEE $40^{\text {th }}$ International Conference on Electronics and Nanotechnology (ELNANO), Ukraine, Kyiv 2020, 216.

[33] Kahar Mr., Macwan A., Oza Ms. et al.: Int. J. Eng. Res. Appl., 2013, 3, 441.

[34] Aladjem A.: J. Mater. Sci., 1973, 8, 688. https://doi.org/10.1007/BF00561225

[35] Chang H., Choe B.-H., Lee J.: Mat. Sci. Eng. A, 2005, 409, 317. https://doi.org/10.1016/j.msea.2005.03.114 
Studying the Insulating Properties of Oxide Films Obtained on the Ti6A14V Alloy in Tartaric Acid... 535

[36] Pancheva H., Reznichenko G., Miroshnichenko N. et al.: EEJET, 2017, 4, 59. https://doi.org/10.15587/17294061.2017.108908

[37] Pilipenko A., Maizelis A., Pancheva H. et al.: Chem. Chem. Technol., 2020, 14, 221. https://doi.org/10.23939/chcht14.02.221 [38] Pilipenko A., Pancheva H., Reznichenko G. et al.: EEJET, 2017, 1, 21. https://doi.org/10.15587/1729-4061.2017.95989

[39] Diao R., Rong J., Wang X. et al.: Int. J. Electrochem. Sci., 2018, 13, 7765.

[40] Silchenko D., Pilipenko A., Pancheva H. et al.: EEJET, 2018, 4, 35. https://doi.org/10.15587/1729-4061.2018.140554

[41] Aarão Reis F.: Condens. Matter Phys., 2017, 20, 1. https://doi.org/10.5488/CMP.20.33803

Received: May 21, 2020 / Revised: August 06, 2020 / Accepted: September 13, 2020

\section{ДОСЛІДЖЕННЯ ІЗОЛЮЮЧИХ ВЛАСТИВОСТЕЙ ОКСИДНИХ ПЛІВОК, ОТРИМАНИХ НА СПЛАВІ TI6AI4V У РОЗЧИНАХ ТАРТРАТНОЇ КИСЛОТИ, МЕТОДОМ ЕЛЕКТРОХІМІЧНОГО ДЕКОРУВАННЯ МІДДЮ}

Анотація. Представлені результати дослідження особливостей формування оксидних плівок на сплаві Ti6Al4V у розчинах тартратної кислоти. Показано, щзо характер формувальних залежностей сплаву обумовлюється анодною густиною струму. 3 а $j_{a}<0,5 A \cdot \partial \mu^{-2}$ суцільна оксидна плівка на поверхні сплаву не утворюється $i$ задане значення кінцевої напруги на коміриі не досягається. При підвищенні до $j_{a}>0,5 A \cdot \partial M^{-2}$ формувальні залежсності мають лінійний характер, що свідчить про утворення малопористих плівок. Швидкість формування оксидної плівки за ичих умов прямо пропориійна величині $j_{a}$. Результатом електрохімічного окиснення сплаву Ti6Al4V у тартратних розчинах є утворення інтерференційної-забарвлених оксидних плівок. Гранична товщина $і$ колір оксидної плівки визначаються заданою напругою $i$ не залежсать від густини струму і концентрації електроліту. Ізолюючі властивості отриманих плівок досліджені внаслідок катодної поляризачії оксидованих зразків у сульфатному електроліті міднення. Проведені дослідження дали можливість встановити, що електрохімічне осадження міді є зручним інструментом для виявлення дефектних ділянок оксидних плівок. Показано, щуо внаслідок особливостей кінетики відновлення йонів $\mathrm{Cu}^{2+}$ на оксидованому титані для дослідження ізолюючих властивостей плівок дочільно використовувати початкові ділянки поляризаційних залежностей, які відповідають $\Delta E=0,2-0,25$ В. Результати поляризачійних вимірювань дали можливість встановити, щчо очевидні залежності між густиною струму оксидування, концентраиією електроліту, кінщевим значенням напруги на коміриі і поляризацією при відновленні йонів $\mathrm{Cu}^{2+}$ відсутні. Анодне включення зразків 3 обумовлюс оборотне розчинення більшості острівиів мідного осаду, що, імовірно, вказує на електронну провідність дефектів плівки. Отримані результати дають можливість проводити зміну параметрів електролізу у широкому діапазоні без значного впливу режниу оброблення металу Ti6Al4V на якість оксидних покриттів

Ключові слова: анодна поляризація, оксидна плівка, електрохімічне осадження, поляризаційна залежність. 